\title{
ALICE: Arts Lab in Interfaces, Computers, and Everything Else - Research report (2019)
}

\author{
Flávio Luiz Schiavoni, André Lucas Nascimento Gomes, Avner Maximiliano de Paulo, \\ Carlos Eduardo Oliveira de Souza, Fábio dos Passos Carvalho, Frederico Ribeiro Resende, \\ Gabriel Lopes Rocha, Igino de Oliveira Silva Junior, Igor Alves Estevam Andrade, \\ João Teixeira Araújo, Luísa Lugon-Moulin Brazil Santos, Luan Luiz Gonçalves, \\ Mauro César Fachina Canito, Octávio Ferreira Deluchi Cerqueira da Silva, \\ Rômulo Augusto Vieira Costa, Thiago de Andrade Morandi, Valdir de Siqueira Santos Junior \\ ${ }^{1}$ Arts Lab in Interfaces, Computers, and Everything Else - ALICE \\ Federal University of São João del-Rei - UFSJ \\ São João del-Rei - MG \\ fls@ufsj.edu.br
}

\begin{abstract}
Located in the Computer Science Department of the Federal University of São João del-Rei, but not limited to just this space, ALICE has emerged as a research group focused on the development of software, art and technologies for the area of computer music and digital arts. Over the time, ALICE became the laboratory to develop technologies to an artistic group, called Orchidea, focused on the creation of digital art, encompassing students from diverse areas, such as Computer Science, Scenic Arts, Architecture and Music in a transdisciplinary context of art creation. In this way, this work aims to present the various initiatives and proposals carried out by the ALICE, addressing the development of technological products, through the tools implemented and the external tools used for teaching and for artistic creation. In addition, this work describes the current researches that are under development by the members of the groups, also highlighting the development of the digital performance titled "O Chaos das 5" and all the aspects and learning that we have obtained so far with this performance.
\end{abstract}

\section{Introduction}

$\mathrm{ALICE}^{1}$ is the name of a laboratory in the Computer Science Department at the Federal University of São João delRei. The name of the lab is an achronimous to Arts Lab in Interfaces, Computers, and (Education, Exceptions, Experiences, Entertainment, Environment, Entropy, Errors, Everything, Else and Etcetera...). This name is also a good hint to understand some concepts about the lab.

Firstly, a direct reference to Lewis Carroll book, Alice in the wonderland, can bring the idea of some nonsense, fantasy and peculiar ideas that could guide researches on the lab. Lewis Carroll, a mathematician, used logic to entertain child and to create art. Certainly it is not a "really serious" lab and we believe that it is possible to have interesting computer science involving, mathematics, arts and humanities. Secondly, it is an Art Lab. The presence of arts in the name can be another good hint to understand that we are worried about creative process and some ephemerous software creation, group performance and so on. We are also worried about interfaces and how the man

\footnotetext{
${ }^{1}$ https://alice.dcomp.ufsj.edu.br/.
}

can interact with the world, specially when involving computers to perform this interaction. Thirdly, the infinity possibilities of an open name, that includes everything else, can really be a good chance to keep an open mind when thinking about computer science and art research.

Most part of the members of this lab are computer science undergraduate students, studying computer science. There are also computer science master's students (PPGCC - Programa de Pós Graduação em Ciência da Computação) and master's students in Arts, Urbanities and Sustainability (PIPAUS - Programa Interdepartamental de Pós-graduação Interdisciplinar em Artes, Urbanidades e Sustentabilidade). Since ALICE started to be an laboratory to art creation, some students in Music, philosophy, scenic arts, applied arts and also professors from different areas joined us in some projects.

In this paper, written by several hands, we will present the current research, art creation and software developed in this lab.

\section{Teaching and learning - The STEAM}

Since our University has no course on Digital Arts, our students has a few options of courses to get involved in this subject. There is only one course, Introduction to Computer Music, available to undergrad students into Computer Science. To Master's students there are two courses, Digital Arts and Immersive performance in Scenic Arts. Thus, the get involved in the areas of digital art, it is necessary some complementary studies.

Inspired by the concepts of the STEAM framework [1], ALICE supports a group that bring discussions from different points of view in the STEAM areas. STEAM is basically an educational system where through art, students are introduced to concepts related to Science, Technology, Engineering and Mathematics.

Regarding the issues studied within the study group, it was discussed how some mathematical definitions, such as Symmetries, Fractals, Fibonacci numbers, among others, could be applied through several areas such as Computer Science, Music, Architecture, Photography and Applied Arts, all with their respective points of view, 
employing these concepts under various types of media, such as images, videos, and audios.

By having a heterogeneous group of members, diverse departments and with a completely different experience and formation brings a collaborative and immersive environment where it becomes a place the members acquire an evolution of their work under the influence of other factors, apart from their experience.

\section{Art Creation - The Orchidea}

To try to reach some art creation, we also created an art group, called Orchidea. The Orchidea - an Orchestra of Ideas, focuses on the development of collaborative art and the creation of an environment that encompasses students from diverse areas, be it theater, music, computer science, architecture, philosophy and others, to create art together. By approaching this transdisciplinary concept, Orchidea ends up being a very promising environment in relation to the collective learning of the students, since students from different areas, have different abilities, which in group, can be shared, making the students help each other among themselves, overcoming their difficulties.

Initially, the idea of the name of the group appeared in 2015, with the implementation of the tool called Orchidea [2]. This tool was a mobile application, implemented in Java, where its purpose was to enable the creation of a mobile orchestra. The application was developed by an undergraduate student, who at the end of his monograph, ended up giving no continuity to the project.

In 2016, as a final result of the discipline of Introduction to Computer Music, Orchidea was resumed, gaining a second version, now based on the Web Audio API and mobile device sensors. Finally, in 2018, based on the need to create art and study new aesthetic concepts associated with technologies, our digital art group was finally created.

Currently, Orchidea has undergraduate and graduate students, and its objectives can be described as:

- Fostering and performing digital artistic creations;

- Integrate transdisciplinary knowledge of different areas through art;

- Stimulate the collective and collaborative creation of art supported by the computer;

- Use affordable and more sustainable technology for artistic creation;

- Use and create free software for the diffusion of artistic creation and Enable public participation in the presentation and artistic creation that can happen anytime, anywhere.

\subsection{Current Art Creation - O Chaos das 5}

As a more significant result developed by Orchidea, one can highlight the digital performance called "O Chaos das 5", already presented in São Paulo, Belo Horizonte, Conselheiro Lafaiete, Mariana and São João del-Rei. This performance is a spectacle that involves the use of technology, besides providing the interaction of the public, which ends up taking a more active position during the play, influencing it and becoming an artist and not just part of the public.

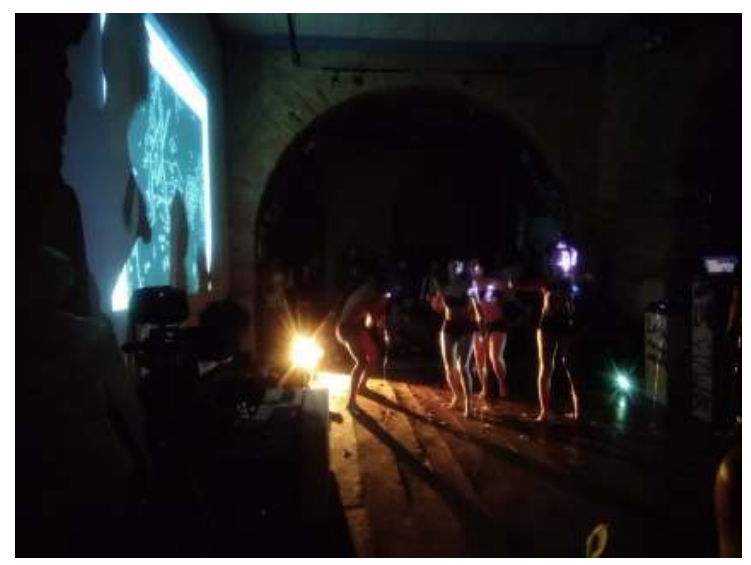

Figure 1: Digital Performance "O Chaos das 5"

The performance was developed in the city of São João del Rei in 2018, with the support of the ALICE laboratory, in conjunction with the ECOLAB / Movére research laboratory of the Performing Arts course. In "Chaos das 5 " technology influences audience experience and is influenced by audience interaction through mobile devices, where the whole plot is given by three layers: visual layer; gestural layer and musical layer.

The visual layer is based in images created in real time, projected on the walls, presenting the aesthetics of placing the computer in the scene, aiming at the idea of opening the "Black Box", showing how the work is developed and not just its respective end result $[3,4]$. The gestural layer has a performance that mixes scores of gestures and improvisations in an immersive theater that allows physical interaction with the audience in the space of the show, encompassing artists who interact with the audience during the performance. Finally, the musical layer with DMIs to be accessed by the public by their mobile devices, in addition to having musicians improvising with their unconventional digital instruments $[5,6]$.

In relation to the tools developed for the performance, it is worth mentioning the creation of DMIs for the audience, DMIs for our musicians, visual effects, image processing applications, image synthesis, Pure Data patches, web audio instruments and more. All the technology used in this performance was made in ALICE and is the outcome of a student's research.

\section{Current Research}

Currently, our group has carried out several researches in several areas related to Computer Music / Digital Art. This subsection will present the work done by ALICE, giving a brief explanation of what has been developed, in addition to the ongoing research.

\subsection{Digital Musical Interfaces}

The creation and use of Digital Music Instrument (DMI) is one of the lines of research that is currently being devel- 
oped in our group. Unlike an acoustic instrument, where the creation of an instrument goes through a long period of trial and error, a digital instrument has as its characteristic that in its conception process, the developer looks for achieve a certain goal [7].

This research aims at studying the creation of DMIs from ubiquitous devices, raising several implementation aspects, such as which forms of mapping will be implemented. Mapping is a nice subject to explore when creating new instruments since they can be from the simplest, one-to-one, where a button is responsible for to play only one note, to the more complex ones, many-to-many, where a sequence of buttons can perform certain actions, which in turn can also influence future actions. It is worth mentioning that all the design decisions raised during the development of an DMI are studied as well as the considerations on how the creative process can influence and be influenced by the technological decisions used.

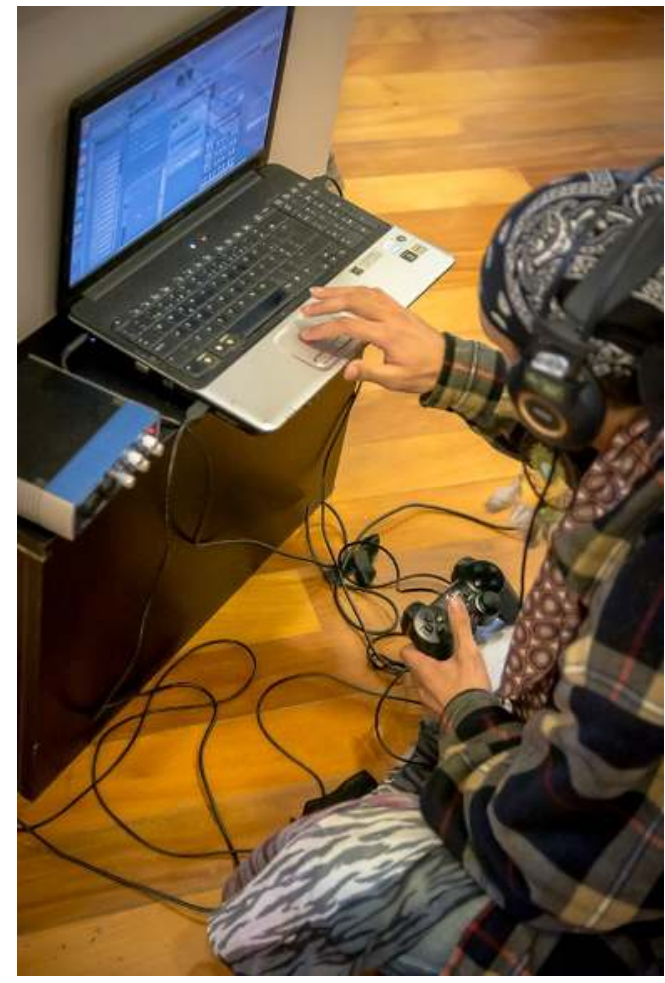

Figure 2: DMI development based on the joystick

For instrument development, we must work under the construction of three modules: Firstly, one must obtain or produce an iteration device, so that it is an interface where it is usual and interesting for the musician to perform on it. Examples of elements used as interface are buttons and knobs of MIDI devices and Joysticks [8], the capture of movements through cameras [7], smartphones [9] and their sensors, among others.

Another tool that has to be used is an apparatus that synthesizes the media that the instrument reproduces. In addition to reproducing the media thought by the creator of the instrument, via images, sounds, actuators and others, it must be able to return feedback to the user of the instrument, so that it can perform an action from this feedback.

Finally, the composer of the instrument must interconnect the two previous elements via a mapping module. These combinations of connections made by the creator will define how it will work and control the component it interacts on the synthesizer.

In our laboratory, we had several initiatives of DMI development, like a Joystick do play music (presented in Figure 2 or web browser based instruments (Figure 3).

\subsection{WebArt}

Since the early days of computing artists have been using computers as tools to support their traditional artistic creations. This includes the various areas of art such as photography, painting, theater, dance, music, architecture, sculpture and literature, for example, domains that have been radically impacted by the emergence of computational support. Over time, the computer has gone from being a tool to support the traditional arts (from the so-called Fine Arts to the so-called "Minor Arts" as the craft) for a specific creation tool and not tied to the conventional arts. This allowed the emergence of another type of art, possible only through electronic devices, called Digital Art. Digital Art emerges as a convergence between Art, Science and Technology and has brought artists new challenges for artistic creation in the digital universe [10]. This Digital Art includes several new forms such as Media Art, net art, digital installations and Virtual Reality as a form of Art [11].

However, with the emergence of the Internet, the web started to arouse the interest of several areas, including art. The Internet was initially used as a way of distributing traditional art, through shops, museums and virtual art galleries, and also as a way of making art by allowing multimedia creation and being present at the center in the technological revolution of information [12]. This art form, called Web Art, includes several artistic creations made especially for the web [13].

Thus Web Art can be characterized as a category of digital art that only occurs for and through the internet, being worked in the web environment has a huge range of possibility, yet has as its main feature the interactivity, which gives the user the possibility of interacting with your content, in a scheduled or real-time manner.

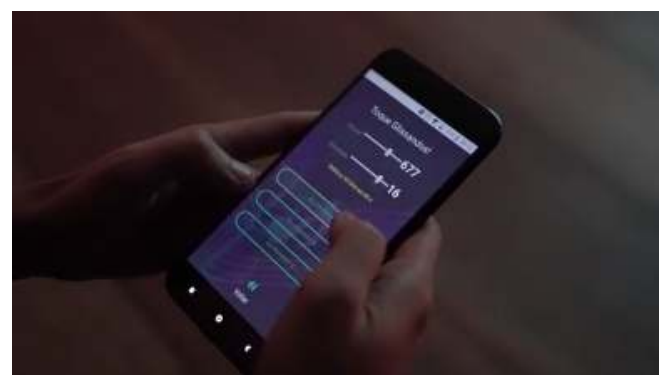

Figure 3: Web based DMls developed with Mosaicode to the performance O Chaos das 5 
In our laboratory, several initiatives using web art were developed [14, 15, 16, 17, 18]. From web based DMIs (Figure 3) to visual arts (Figure 4) and video collage performance. Our group also conducts research to explore the principle of digital art and how it, developed to work with any electronic devices, evolved into web art, tools available in HTML for the development of web sites aimed specifically at the artistic making, which differ from the traditional pages developed only from artistic purposes. In this way, discussions about the beginning of the web art are carried out, addressing how were the environments of creation of the first web arts, what are the resources available in the initial versions of HTML, besides what are the new tools and new possibilities of web creation art that HTML5 brought to the surface with its emergence.

\subsection{Creative process and collaboration in art creation}

The term "creative process" characterizes the methods used by creators in the composition of their artistic products, and this action is performed in any subdivision of the art. It is an action of semantic and semiotic translation, where the whole process of artistic production is based on a repertoire, be it of memories, concepts or other subjectivities. This first sums up a second repertoire of material elements such as colors, words, sounds and forms, within a creative phenomenological instance, which will be the creative and communicational selection screen that will conceive the final artistic product [19].

In short, the creative process can be associated with Dewey's philosophy, which treats the artistic method as an organic process, which consists of a trajectory from gestation to maturation. Therefore, the work of art is not inseparable from its creative process, since the games of trial and success, waiting and discovery, between the stages of idealization, execution and conception, all of these compose temporal instants which resulted in the finished work of art [20].

Uncharacterized from a set of rules that govern their formation, the artistic creative process has only one premise to be followed, that "the rule of art is the criterion of success" [20]. In other words, the process of artistic creation is limited only by the very rule that art imposes on it to conceive itself, so dualities such as rigor and spontaneity are not expressed as absolute rules, where only the inventiveness and originality of the artist should flourish.

In ALICE, the creative process is a subject always explored, specially the collective creation, cooperative creation and the use of technology to aid creative process in a group context $[21,6,22,23,24,25]$. We also strongly believe that it is possible to attach software development to art creation and understand the creativity to develop computer algorithms as a special case of art creativity.

\subsection{Computer Music Programming Languages}

The area of computer music is strongly based on the generation of audio via computer, which is usually created under a software system, which in turn is developed under software development methodologies that encompass programming, from programming languages, that are directed to the expression of audio synthesis and processing, culminating in the emergence of several non-conventional computational solutions. In relation to the programming languages used to perform any computational task, they are under constant influence of evolution and innovation, and these languages are the focus of some theoretical and practical research developed on ALICE.

An example of these theoretical research is a general study of different languages with different paradigms, in the Computer Music domain, addressing the historical questions of the evolution of these languages, their technical and developmental issues, taking into account ease of use and criteria such as readability, expressiveness and ease of writing [26, 27].

Some of the theoretical research on musical programming languages is used to help the development of the Mosaicode environment, a visual programming environment for code generation of Domain-Specific Languages (DSLs), that aims to help novices to create applications in Digital Art areas such as Computer Music, Computer Vision and Computer Graphics.

\subsection{Audience Participation and interaction in Digital Performance}

The research in the area of digital performances includes musical performances and theatrical shows that involve various aesthetic concepts related to some kind of technology for their execution, whether they are sensors, cell phones, or some another technological resource. Through an in-depth study of the digital performances until then, this research aims to understand how the public interaction in these events is given, raising aspects about what should and should not be done so that the gap between the definition of who is public and who is an artist becomes more and more narrow, without the engagement of the participants being compromised.

Still on digital performances, the audience's interaction can be done in several ways. In our lab we are exploring the audience participation via mobile phones, which are used in the form of DMIs, enabling the public to actively participate in the performance by generating music from mobile devices [25, 14, 9, 28, 24].

\subsection{Art and Sustainability}

Another area of research addressed by the group is art and sustainability, which looks for use computational arts in the development of a sustainable consciousness based on the Brundtland Report [29]. Among the issues addressed in this report, we can highlight the reduction of energy consumption, the development of technologies using renewable energy sources and the increase of industrial production in non-industrialized countries based on ecologically adapted technologies, which are directly linked to the computational area.

In ALICE, the sustainability art and technologies follow the ideas of sustainability involving social, econom- 


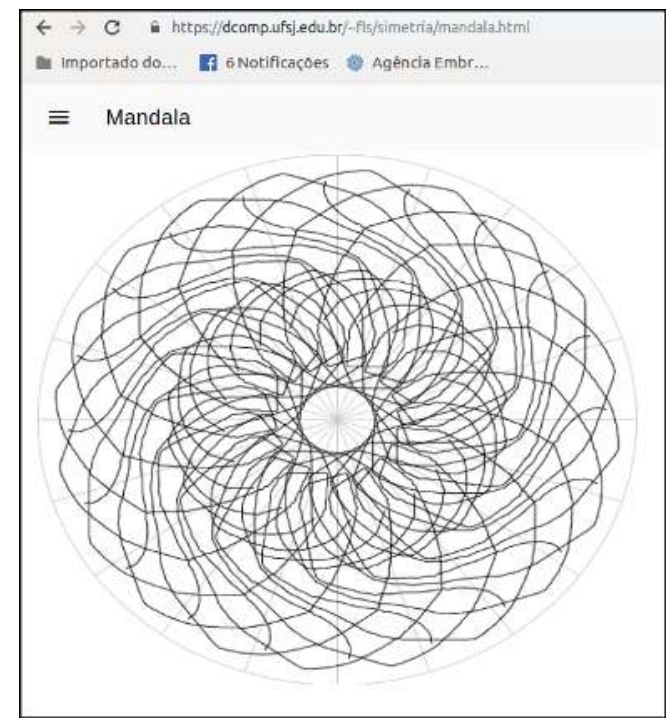

Figure 4: Web based interface that explores symmetry in visual arts

ical, cultural and environmental sustainability [30, 31]. Initially, it is worth mentioning that in ALICE only free software are used and developed [32]. All tools used in our group are open, modular and based on code reuse. In order to ensure greater compatibility, in addition to ensuring aesthetic possibilities, ALICE works with open protocols, file formats and systems compatible with legacy systems and other platforms. In this way, we believe that we are not only creating new technological tools, but we are also allowing others to use them to create art or even to learn computing.

The usage of open source tools, open hardware, open source libraries and all kind of open technology is mandatory. Also, the usage of ubiquitous devices that do not demand expensive technology is also a guideline. Thus, this interaction of the public with sustainable artistic production would to potentiate the development of an awareness based on the Brundtland Report, making sustainable computer art reach its goal.

Another concern focusing sustainability in our lab is about how to combine new technology with old culture from our land. The research involving cultural sustainability led us to bridge cultural aspects of our society with digital arts, like in our soundscapes projects involving church bells and ubiquitous technology [33, 22, 23, 34, 35].

\section{Software development focused on Arts}

Beyond theoretical researches and art creation, ALICE has developed a few technologies. The most part of the software developed in our lab are only prototypes and ephemeral code but some of them should be mentioned here.

\subsection{Mosaicode}

Mosaicode is a visual programming environment geared towards the Digital Art domain [36, 37]. It works from blocks, which are elements with specific and atomic functionalities on a domain, and connections, which connect these blocks and perform data transmission between them. Connections and blocks together form a diagram, which is an abstraction of an application. With this artifact, it is possible to generate, execute or edit the code of an application. This capability allows the environment to be a powerful software for programming, as well as enabling rapid prototyping and coding. The tool, besides being open-source, is extensible. Each extension allows the user to be able to use concepts related to the domain in which the extension belongs. If it is in the user's interest, the environment provides the same viability to freely create its own extension, representing the domain of its purpose.

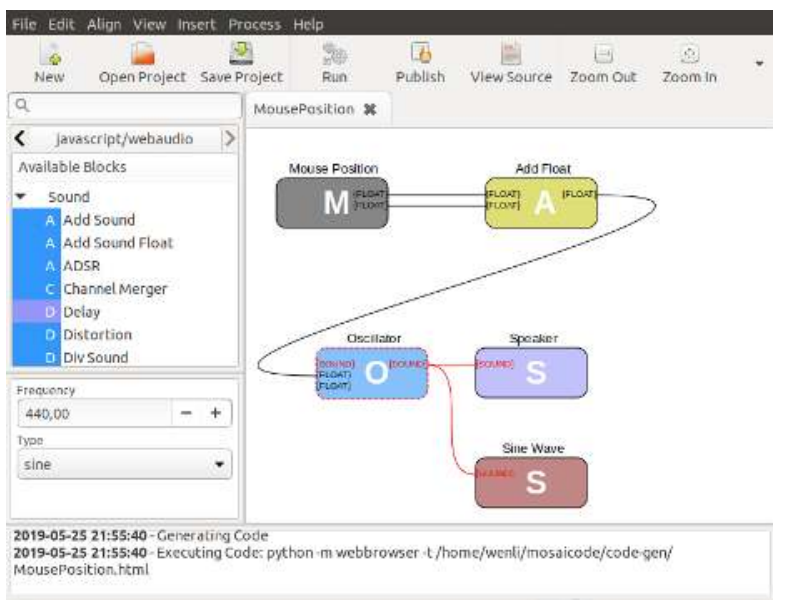

Figure 5: Visual Programming Environment Mosaicode

The tool emerged in 2014, based on the refactoring of Harpia, a tool for training and management of computer vision systems, created by $S 2 i$ in the Federal University of Santa Catarina (UFSC), where its architecture was completely altered and the code completely rewritten to use extensions and plugins.

The environment has applications for teaching [38], digital art creation, software prototyping and more. Most part of the instruments and visual creations used in the performance "O Chaos das 5 " were created using Mosaicode.

\section{Mosaicode to Image Processing \& Computer Vision}

One of the extensions already developed for the Mosaicode environment deals with the domain of Digital Image Processing and Computer Vision [39]. It provides about 65 distinct features addressing both named areas, using OpenCV framework in $\mathrm{C}++$ language, acquiring computational efficiency in the generated code.

Among these functionalities, there are blocks that portray mathematical, logical, morphological, data generation and synthesis, low-pass and high-pass filters, pattern detection and a variety of other algorithms, and operations that address signal processing techniques in images. 


\section{Mosaicode to Image Synthesis}

In development process since 2017, the Extension of Image Synthesis of Mosaicode was developed under the OpenGL graphics library under the $\mathrm{C} / \mathrm{C}++$ programming language [39].

Currently the extension has 44 blocks distributed in 8 categories: 2D Shapes and 3D Shapes, with twodimensional and three-dimensional models, respectively; Artistic, where they use representations of mathematical definitions discussed in the STEAM study group as fractals and symmetries abstracted in blocks; I / O, where it has control blocks for the generated application; Math, mathematical operations on top of float values; Operations, to perform geometric transformations under the rendered forms; Types, which declare variables to initialize other blocks and Window, where parameters of the created window are modified. To make the connection between these blocks, 3 types of ports have been developed: Color, Float and Flow.

\section{Mosaicode to Audio Processing}

Developed in $\mathrm{C} / \mathrm{C}++$ and based on PortAudio API and libsoundfile, there is an extension to Mosaicode to develop audio applications, focused on providing resources for working with sound design. This extensions includes blocks to DSP processing, like filters, audio sources, like noise and oscillators, audio input, output and blocks to open / save audio files.

\section{Mosaicode to Web Art}

The Mosaicode also has an extension to create Web Art based on the HTML5 APIs [40, 41]. This extension allows to create audio synthesizers using the JavaScript / Web Audio API, which is also geared towards Web Art development. This extension has blocks to play audio files, access microphone, create oscillators, noises and more. Among the various categories of Blocks implemented, we have until then: Sound Sources; Audio Filters; Logical and Arithmetic Operations; and Input Devices.

\subsection{Glue Tube}

GlueTube is a tool capable of manipulate YouTube videos through an HTML5 API to generate a montage with the videos being shown on the computer screen. The arrangement of the videos can be controlled by the settings on the project and the tool also allows to create a .XML file that works like a score, to indicate the youtube video parts and how many times it should be executed.It is also possible to indicate the position on the screen and the size of the video.

Despite the possibility of creating a score, it is possible to mix the videos in real time, like in a musical improvisation performance, and use the score like a backing track to improvise over that.

The conception of this tool was based on Pierre Schaeffer's concrete music and the collage art, a technique which is very popular in the web art, applied to the YouTube collection. However, in order to follow YouTube's copyrights rules, the infringement has been considered and we created a tool capable to use fragments of YouTube videos, online, with no necessity of downloading them.

\subsection{Ha Dou Ken Music DMI}

As discussed in subsection 4.1, the creation of DMIs is a very present area in our research lab. One of the works related to the creation of a musical instrument is the "Ha Dou Ken Music DMI" [7, 8, 42].

This work aims to use video game controls as an interface for musical interaction, taking into account its great presence in popular culture and its ease of access for low prices. Even people who are not in the habit of playing electronic games have possibly already interacted, at some point, with that kind of control. Interactions like pressing a sequence of buttons, pressing them simultaneously, or sliding the fingers through the control, are often present in fighting games like Street Fighter and are used in this instrument to create music.

In this way, the main objective of this instrument is the elaboration of a strategy in which several gestures captured by the interface can influence one or even several sound parameters. That is, the challenge lies in the elaboration of several mapping techniques, be they the simplest, such as the one-to-one mapping where a button causes a certain result that is always static, to the more complex ones, such as the many-to-many mapping, exploring greater expressive video game control capabilities from capturing complex moves. These mappings are performed based on the MIDI protocol, which give us access to a large number of compatible synthesizers.

It is worth emphasizing that experiments show that this choice is capable of influencing the musical expression made possible by a DMI, which makes it closer to a "real instrument", being in this way more pleasurable and challenging to play. This instrument is used in the performance "O Chaos das 5".

\section{Final Considerations}

From the course of Introduction to Computer music, taught in 2014 at the Federal University of São João del-Rei delRei, and also from the interest of some students to continue their studies in the area of Computer Music and Digital Arts, was created ALICE.

Since then, this laboratory has worked extensively on research aimed at technological creations, covering several areas, among them Computer Science itself and also Music, Architecture, visual arts and Theater. This transdisciplinary character brought us positive aspects, since people from different areas have different abilities and ways of thinking. The difference between the students, when analyzed under the collaborative knowledge provided, is quite promising because the students can help each other, making the difficulties of each one overcome from the support provided by the group in general. 
Besides the research developed by ALICE, we have the development of software for the creation of digital art. This development provided the opportunity to the students involved with it to think beyond the code while developing a software. Several times it was necessary to think artistically, carrying out a study of the aesthetics that involves the creation of an artistic application, thinking in the creation of digital art and not only in technological tools, accepting borders and limitations, striking with latency and performance issues, trying to not think only in developing codes but in the creation of an art piece.

Computer students generally think only as scientists and almost never as artists. From the creation of the Orchidea group, which is also a consequence of the creation of ALICE, we have been able to break this barrier. Coming in contact with people and working in other areas, all the students involved have changed greatly from the development of the main work of Orchidea, the digital performance "The Chaos das 5". This performance brought with it some technical issues and difficulties that until them many of those involved had not witnessed. Among the problems we have: computational situations, such as the treatment of scalability in high-scale performances and the development of DMIs used; and problems related to the production / execution of a performance, where those involved need to deal with the production of a script that involves references that are not common in a Computer Science course, the allocation of the space to be used, in addition to determining which types of interactions would or would not engage the participating public, and more and more.

Finally, the creation of a research group in the academic environment has much to offer in the development and growth of all people involved, both as students and individuals. It is noteworthy that in the academic environment, specifically in a Computer Science Department, there is a certain difficulty / barrier to creating a group of transdisciplinary digital art, perhaps because of bureaucratic or even cultural issues. However, the creation of ALICE / Orchidea / STEAM has shown us the potential of collaborative work, since we could observe the evolution and development of skills in several students, writing / presenting scientific articles and even improving the ability to deal with people in general.

\section{Acknowledgments}

Authors would like to thanks to all ALICE members that made this research and development possible. The authors would like also to thank the support of the funding agencies CNPq and FAPEMIG.

\section{References}

[1] Lisa G Catterall. A brief history of stem and steam from an inadvertent insider. The STEAM Journal, 3(1):5, 2017.

[2] Flávio Luiz Schiavoni and Paulo Gabriel Nunes Cançado. Orchidea: Os meta-instrumentos da orquestra de ideias. Revista Vórtex, 6:1-18, 2018.
[3] João Teixeira Araújo, André Lucas Nascimento Gomes, Frederico Ribeiro Resende, and Flávio Luiz Schiavoni. As poéticas visuais do "o chaos das 5". In Anais da $2^{a}$ Semana Acadêmica Integrada dos Cursos de Letras / $15^{a}$ Semana Acadêmica do Curso de Letras, pages 1-1, São João delRei, 2019.

[4] Valdir de Siqueira Santos Junior and Flávio Luiz Schiavoni. Quando a rua entra em cena: uma apropriação do discurso do pixo na performance "o chaos das 5". In Anais da $2^{a}$ Semana Acadêmica Integrada dos Cursos de Letras / $15^{a}$ Semana Acadêmica do Curso de Letras, pages 1-1, São João del-Rei, 2019.

[5] Carlos Eduardo Oliveira de Souza and Flávio Luiz Schiavoni. O discurso da guitarra no espetáculo "o chaos das 5". In Anais da $2^{a}$ Semana Acadêmica Integrada dos Cursos de Letras $/ 15^{a}$ Semana Acadêmica do Curso de Letras, pages 1-1, São João del-Rei, 2019.

[6] Octávio Ferreira Deluchi Cerqueira da Silva and Flávio Luiz Schiavoni. Diálogo sonoro em chaos das 5, das ruas ao concreto e sintético. In Anais da $2^{a}$ Semana Acadêmica Integrada dos Cursos de Letras / $15^{a}$ Semana Acadêmica do Curso de Letras, pages 1-1, São João del-Rei, 2019.

[7] Gabriel Lopes Rocha, Avner Maximiliano Paulo, João Pedro Moreira, and Flávio Luiz Schiavoni. Desenvolvimento de Instrumentos Musicais Digitais a partir de dispositivos ubíquos. In Proceedings of the VIII Workshop on Ubiquitous Music (UBIMUS), volume 8, pages 98-110, São João del-Rei - MG - Brazil, 2018.

[8] Gabriel Lopes Rocha, João Teixera Araújo, and Flávio Luiz Schiavoni. Ha dou ken music: Different mappings to play music with joysticks. In Marcelo Queiroz and Anna Xambó Sedó, editors, Proceedings of the International Conference on New Interfaces for Musical Expression, pages 77-78, Porto Alegre, Brazil, June 2019. UFRGS.

[9] João Teixeira Araújo and Flávio Luiz Schiavoni. A participação do público em performances artísticas por meio do uso de dispositivos móveis. In Anais do 50 . Seminário de Artes Digitais 2019, pages 203-211, Belo Horizonte, 2019.

[10] Oliver Grau. Virtual Art: from illusion to immersion. MIT press, 2003.

[11] Bruce Wands. Art of the Digital Age. Thames \& Hudson, 2007.

[12] Mark Tribe, Reena Jana, and Uta Grosenick. New media art. Taschen London and Cologne, 2006.

[13] Annette Weintraub. Art on the web, the web as art. Commun. ACM, 40(10):97-102, October 1997.

[14] Igino de Oliveira Silva Júnior, Flávio Luiz Schiavoni, Adilson Roberto Siqueira, and Marcela Alves de Almeida. A interatividade do chaos das 5. In Anais do 5o. Seminário de Artes Digitais 2019, pages 115-122, Belo Horizonte, 2019.

[15] Avner Maximiliano de Paulo and Flávio Luiz Schiavoni. A web arte: de linguagens de programação à linguagens artísticas. In Anais da $2^{a}$ Semana Acadêmica Integrada dos Cursos de Letras / $15^{a}$ Semana Acadêmica do Curso de Letras, pages 1-1, São João del-Rei, 2019.

[16] Flávio Luiz Schiavoni, Luan Luiz Gonçalves, and José Mauro Silva Sandy. Mosaicode and the visual programming of web application for music and multimedia. Música Hodie, 18:132-146, 2018.

[17] Roberto Piassi Passos Bodo and Flávio Luiz Schiavoni. A sonification approach to music visualization. In Interna- 
tional Conference of Students of Systematic Musicology, pages 52-57, Belo Horizonte - MG - Brazil, 2018.

[18] Roberto Piassi Passos Bodo and Flávio Luiz Schiavoni. Synesthesia add-on: a tool for html sonification. In Proceedings of the 16th Brazilian Symposium on Computer Music, pages 75-80, São Paulo - SP - Brazil, 2017.

[19] Max Bense and Elisabeth Walter. La semiótica. 1975.

[20] Luigi Pareyson and Maria Helena Nery Garcez. Os problemas da estética. Martins Fontes, São Paulo, 1997.

[21] Thiago de Andrade Morandi, Flávio Luiz Schiavoni, and Zandra Coelho de Miranda Santos. AnÁlises de processos criativos influenciados pelo espaÇo e memÓria. Art \& Sensorium, 5:55-68, 2018.

[22] Thiago de Andrade Morandi and Flávio Luiz Schiavoni. Processos criativos de foley, soundscape e música ubíqua em produções audiovisuais. In Anais do Jornada Interdisciplinar de Som e Música no Audiovisual, pages 1-1, Rio de Janeiro, 2019.

[23] Thiago de Andrade Morandi and Flávio Luiz Schiavoni. EstÉtica relacional e registro ubÍquo de paisagens urbanas nos processos criativos. In Anais $5^{\circ}$ Colóquio IberoAmericano: paisagem cultural, patrimônio e projeto, pages 1-2, Belo Horizonte, 2019.

[24] Flávio Luiz Schiavoni, Eduardo Silva Xavier, and Paulo Gabriel Nunes Cançado. (Orchidea) Uma primeira aplicação para práticas musicais coletivas na Orquestra de Ideias. In Proceedings of the VIII Workshop on Ubiquitous Music (UBIMUS), volume 8, pages 120-131, São João delRei - MG - Brazil, 2018.

[25] Flávio Luiz Schiavoni, Pedro H. de Faria, and Jônatas Manzolli. Interaction and collaboration in computer music using computer networks: An ubimus perspective. Journal of New Music Research, 0(0):1-15, 2019.

[26] Rodrigo Ramos Araújo, Flávio Luiz Schiavoni, José Mauro Silva Sandy, and Elder José Reioli Cirilo. Estudo e avaliação de Linguagens de Programação Musical. In Proceedings of the VIII Workshop on Ubiquitous Music (UBIMUS), volume 8, pages 86-97, São João del-Rei - MG - Brazil, 2018.

[27] Rodrigo Ramos de Araújo, José Mauro da Silva Sandy, Elder José Reioli Cirilo, and Flávio Luiz Schiavoni. Análise e classificação de linguagens de programação musical. $R e$ vista Vórtex, 6:1-24, 2018.

[28] João Teixera Araújo, Flávio Luiz Schiavoni, and Fábio dos Passos Carvalho. Mediação tecnológica e ubiquidade na participação do público em espetáculos de arte sonora. In Anais do Poderes do som: $I^{a}$ conferência internacional de pesquisa em sonoridades (Powers of sound: 1st international conference on sonorities), pages 148-150, Florianópolis, 2019.

[29] DE BRUNDTLAND RELATÓRIO. Nosso futuro comum. Comissão Mundial sobre Meio Ambiente e Desenvolvimento, 2, 2016.

[30] Marcela Alves Almeida and Flávio Luiz Schiavoni. Aspectos da sustentabilidade e colaboraÇÃo na arte digital. Art \& Sensorium, 5:01-14, 2018.

[31] Marcela Alves Almeida and Flávio Luiz Schiavoni. Do código à colaboração: sustentabilidade na arte digital. In Simpósio Internacional em Artes, Urbanidades e Sustentabilidade, pages 156-164, São João del-Rei - MG Brazil, 2017.

[32] Flávio Luiz Schiavoni. Software livre e sustentabilidade. In Simpósio Internacional em Artes, Urbanidades e Sustentabilidade, pages 175-184, São João del-Rei - MG Brazil, 2017.
[33] Fábio dos Passos Carvalho and Flávio Luiz Schiavoni. Paisagens sonoras: o toque dos sinos na era digital. In Anais da $2^{a}$ Semana Acadêmica Integrada dos Cursos de Letras / $15^{a}$ Semana Acadêmica do Curso de Letras, pages 1-1, São João del-Rei, 2019.

[34] Fábio dos Passos Carvalho, João Teixera Araújo, and Flávio Luiz Schiavoni. Os sinos na era da ubiquidade: a relação entre as tecnologias e o patrimônio histórico. In Anais do Poderes do som: $I^{a}$ conferência internacional de pesquisa em sonoridades (Powers of sound: 1st international conference on sonorities), pages 153-155, Florianópolis, 2019.

[35] Thiago de Andrade Morandi and Flávio Luiz Schiavoni. Os registros ubíquos das paisagens: da imagem ao som. In Proceedings of the VIII Workshop on Ubiquitous Music (UBIMUS), volume 8, pages 66-75, São João del-Rei - MG - Brazil, 2018.

[36] Flávio Luiz Schiavoni, José Mauro da Silva Sandy, Thiago Tadeu Souto Cardoso, André Lucas Nascimento Gomes, and Frederico Ribeiro Resende. O ambiente de programação visual mosaicode. In Anais da $9^{a}$ Sessão de Ferramentas do CBSoft, volume 1, pages 25-35. Sociedade Brasileira de Computação, 2018.

[37] Flávio Luiz Schiavoni and Luan Luiz Gonçalves. From Virtual Reality to Digital Arts with Mosaicode. In 2017 19th Symposium on Virtual and Augmented Reality (SVR), pages 200-206, Curitiba - PR - Brazil, Nov 2017.

[38] Flávio Luiz Schiavoni, Thiago Tadeu Souto Cardoso, André Lucas Nascimento Gomes, Frederico Ribeiro Resende, and José Mauro Silva Sandy. Utilização do Ambiente Mosaicode como ferramenta de apoio para o ensino de Computação Musical. In Proceedings of the VIII Workshop on Ubiquitous Music (UBIMUS), volume 8, pages 25-32, São João del-Rei - MG - Brazil, 2018.

[39] André Lucas Nascimento Gomes, Frederico Ribeiro Resende, and Flávio Luiz Schiavoni. Desenvolvimento de extensões de processamento e síntese de imagens para a ferramenta Mosaicode. In Proceedings of the CONFERENCE ON GRAPHICS, PATTERNS AND IMAGES, 31 (SIBGRAPI), pages 1-4, Foz do Iguaçu - PR - Brazil, 2018.

[40] Flávio Luiz Schiavoni and Luan Luiz Gonçalves. Programação musical para a web com o Mosaicode. In Anais do XXVII Congresso da Associação Nacional de Pesquisa e Pós-Graduação em Música, pages 1-6, Campinas - SP - Brazil, 2017.

[41] Flávio Luiz Schiavoni, Luan Luiz Gonçalves, and André Lucas Nascimento Gomes. Web audio application development with mosaicode. In Proceedings of the 16th Brazilian Symposium on Computer Music, pages 107-114, São Paulo - SP - Brazil, 2017.

[42] Gabriel Lopes Rocha and Flávio Luiz Schiavoni. Gesto, linguagem e mapeamento em instrumentos musicais digitais. In Anais da $2^{a}$ Semana Acadêmica Integrada dos Cursos de Letras $/ 15^{a}$ Semana Acadêmica do Curso de Letras, pages 1-1, São João del-Rei, 2019. 